\title{
Efektifitas Penggunaan Inovasi Media Pembelajaran Rope Ladder Physical Activity Dalam Meningkatkan Minat Belajar Anak
}

\author{
Ega Trisna Rahayu \\ Universitas Singaperbangsa Karawang \\ Email: ega.trisna.rahayu@staff.umsika.ac.id \\ Orcid Id:0000-0002-8589-9646

\section{Rina Syafrida} \\ Universitas Singaperbangsa Karawang \\ Email: rina.syafrida@fai.unsika.ac.id \\ Ine NIrmala \\ Universitas Singaperbangsa Karawang \\ Email: ine.nirmala@staff.unsika.ac.id
}

Article received: 02 Januari 2021, Review process: 05 Februari 2021,

Article Accepted: 11 Maret 2021, Article published: 30 Maret 2021

\begin{abstract}
Based on the determination of Coronavirus Disease 2019 (Covid-19) to be a pandemic which was recorded on March 11, 2020 by the Director General of the World Health Organization (WHO). As well as the direction of the President of the Republic of Indonesia through the Ministry of Education and Culture in the issue of Circular Letter Number 15 of 2020 concerning Guidelines for Organizing Studies from Home in the Emergency of the Spread of Covid-19. So in responding to this, to make learning more effective from the Study from Home of Early Childhood Physical Education, the authors develop an innovative learning media "Rope Ladder (Rolade) Physical Activity". This study aims to see the effectiveness of the development of learning media innovation for Rope Ladder (Rolade) Physical Activity in increasing motivation Study from Home for early childhood primary schools in Physical Education learning in Karawang Regency, West Java, Indonesia. The experimental method used was through the design of The OneGroup Pretest-Posttest Design (Fraenkel, 2012) with a sample of Primary School students in the Early Childhood Category at the age of 7-8 years $(n=19)$ determined based on cluster random sampling, and 8 meetings were held at from the Home of Physical Education. The instrument used was a student motivation questionnaire test which was developed based on Ang Chen, Paul W. and Robert P. Pangrazi (2001) in Slameto (2010). Data analysis was performed using T-Test Technology. Hasel showed research that the innovation of learning media for the Rope Ladder (Rolade) Physical Activity can increase the interest in learning from the Home of Physical Education for early childhood school children.
\end{abstract}

Keywords: Innovation; Learning Media; Rope Ladder (Rolade) Physical Activity; Interest to learn; Early childhood. 


\begin{abstract}
Abstrak
Berdasarkan ditetapkannya Coronavirus Disease 2019 (Covid-19) menjadi pandemi yang tercatat tanggal 11 Maret 2020 oleh Direktur Jenderal World Health Organization (WHO). Serta arahan Presiden Republik Indonesia melalui Kementerian Pendidikan dan Kebudayaan dalam terbitan Surat Edaran Nomor 15 Tahun 2020 mengenai Pedoman Penyelenggaraan Study from Home pada Masa Darurat Penyebaran Covid-19. Maka dalam menyikapi hal tersebut, untuk mengefektifitaskan Study from Home pembelajaran Pendidikan Jasmani anak usia dini, penulis mengembangankan inovasi media pembelajaran "Rope Ladder (Rolade) Physical Activity". Penelitian ini bertujuan mengetahui efektifitas pengembangan inovasi media pembelajaran Rope Ladder (Rolade) Physical Activity dalam meningkatkan motivasi Study from Home anak usia dini Sekolah Dasar pada pembelajaran Pendidikan Jasmani di Kabupaten Karawang Jawa Barat Indonesia. Metode eksperimen digunakan melalui rancangan The OneGroup Pretest-Posttest Design (Fraenkel, 2012) dengan sampel siswa Sekolah Dasar kategori Anak Usia Dini pada usia 7-8 tahun $(n=19)$ ditetapkan berdasarkan Cluster Random Sampling, serta dilakukan 8 pertemuan pada Study from Home Pendidikan Jasmani. Instrumen yang digunakan adalah tes angket motivasi siswa yang dikembangkan berpedoman pada Ang Chen, Paul W. and Robert P. Pangrazi (2001) dalam Slameto (2010). Data yang terkumpul dianalisis dengan menggunakan Teknik Uji-T. Hasil penelitian menunjukan bahwa inovasi media pembelajaran Rope Ladder (Rolade) Physical Activity dapat meningkatkan minat Study from Home Pendidikan Jasmani anak usia dini sekolah dasar.
\end{abstract}

Kata Kunci: Inovasi; Media Pembelajaran; Rope Ladder (Rolade) Physical Activity; Minat Belajar; Anak Usia Dini.

\title{
PENDAHULUAN
}

Semenjak awal tahun 2020, situasi dunia sedang waspada pada sebuah virus yang disebut Coronavirus Disease 2019 atau disingkat Covid-19. World Health Organization (WHO) atau Organisasi Kesehatan Dunia menetapkan Covid-19 sebagai pandemi pada tanggal 11 Maret 2020. Menyikapi hal tersebut, pemerintah Republik Indonesia menerapkan peraturan Pembatasan Sosial Berskala Besar (PSBB) yang diberlakukan dalam rangka penanganan Covid-19. Hal ini dilakukan pemerintah dengan harapan virus Covid-19 tidak menyebar lebih luas dan upaya penyembuhan pasien yang terpapar Covid-19 dapat berjalan secara maksimal. Selanjutnya dalam usaha pembatasan sosial ini pemerintah indonesia telah melakukan pembatasan kegiatan diluar rumah seperti kegiatan pendidikan yang telah dilakukan melalui pembelajaran online. Pembelajaran online yang dilakukan dirumah atau Study from Home dilakukan dengan system belajar jarak jauh, dimana Kegiatan Belajar dan Mengajar (KBM) tidak dilakukan secara tatap muka (Hyong Guan, at. Al., 2020). Study from Home bagi anak usia dini (ketegori usia 78 tahun) dalam pendidikan jasmani pada masa pandemi Covid-19 dilakukan dengan menggunakan alat atau media, baik media cetak (modul) maupun non cetak (audio/video), computer atau internet, begitu pula dengan siaran radio dan televisi (Hammami, 2019). Faktanya pada Study from Home anak tidak menutup kemungkinan dapat menjadi kurang aktif dalam menyampaikan aspirasi dan pemikirannya, sehingga efeknya dapat mengakibatkan pembelajaran menjadi 
menjenuhkan. Oleh karena permasalahan tersebut, diperlukan pendorong untuk menggerakan anak agar semangat belajar sehingga dapat memiliki prestasi dalam belajarnya (Beghetto \& Kaufman, 2014).

Dalam etimologi, kata minat atau "interest" yaitu artinya kesukaan, perhatian, dan keinginan. Secara umum, minat merupakan kekuatan yang mendorong anak untuk melakukan sesuatu agar mencapai tujuan. Kekuatan ini diranggsang dari berbagai kebutuhan seperti keinginan yang hendak di penuhi, tingkah laku, tujuan, dan umpan balik (Hellriegel dan Slocum, 2016). Dalam konsep minat dan motivasi terkandung tiga konsep penting yaitu tujuan, pengetahuan dan proses proses metakognitif (Bayners, 2016). Minat juga merupakan keinginan dari seseorang untuk mempelajari sesuatu hal yang nantinya akan menumbuhkan rasa keingintauannya terhadap objek yang sedang di pelajari.

Dalam proses belajar anak diharuskan mempunyai minat, kesukaan, atau kegemaran untuk mengikuti kegiatan belajar yang berlangsung, karena dengan adanya minat pada diri anak akan mendorong anak untuk menunjukan perhatian, aktivitas, dan partisipasinya dalam mengikuti pembelajaran yang berlangsung. Selanjutnya, minat belajar pada anak merupakan faktor piskis yang bersifat non intelektual, peranananya yang khas adalah dalam penumbuhan gairah, perasaan dan semangat untuk belajar dalam kehidupan sehari-hari. Minat belajar pada anak juga merupakan salah satu faktor penting dalam proses mencapai tujuan pembelajaran. Minat belajar timbul karena adanya perhatian yang mendalam terhadap suatu pembelajaran, dimana perhatian tersebut menimbulkan keinginan untuk mengetahui, mempelajari, serta membuktikan lebih lanjut, hal itu menunjukan bahwa dalam minat, di samping perhatian juga terkandung suatu usaha untuk mendapatkan sesuatu dari hasil belajar tersebut. Pada dasarnya minat belajar merupakan penerimaan akan suatu hubungan antara diri sendiri dan sesuatu di luar diri semakin kuat atau semakin dekat hubungan tersebut maka semakin besar minat belajarnya, faktor terpenting dalam membangkitkan minat belajar adalah pemberian kesempatan bagi aak untuk aktif berpartisipasi dalam kegiatan belajar. Dalam situasi pembelajaran pendidikan jasmani, minat belajar mempunyai pengaruh yang besar dalam pelaksananya, karena bila pembelajaran pendidikan jasmani yang dipelajari tidak sesuai dengan minat anak, maka anak tersebut tidak akan belajar dengan sungguh-sungguh, sebab tidak ada daya tarik baginya.
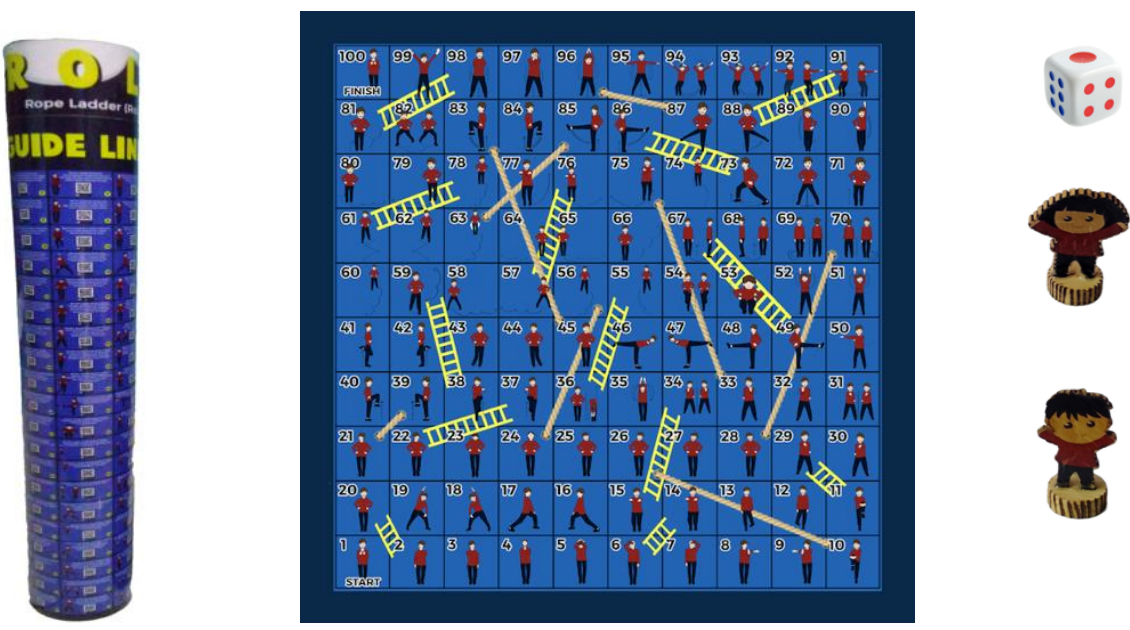
Inovasi media pembelajaran dalam pendidikan jasmani pada anak usia dini yang dinamakan Rope Ladder (Rolade) Physical Activity ini terinspirasi dari permainan ular tangga yang sudah dikenal masyarakat. Rope Ladder (Rolade) Physical Activity merupakan media pembelajaran berbasis permainan berupa Rope (tali) Ladder (tangga) Physical Activity (aktivitas fisik) yang dibuat menyerupai permainan ular tangga, namun aturan permainannya ditambahkan peraturan baru agar pembelajaran menjadi lebih menarik dan tidak membosankan. Kebaruan serta keunikan Rope Ladder (Rolade) Physical Activity dibandingkan dengan permainan ular tangga ialah pada Rope Ladder (Rolade) Physical Activity setiap nomor pada kotak permainan disertakan perintah aktivitas fisik yang gerakannya disesuaikan dengan aspek gerak perkembangan fisik motorik anak usia dini.

Pelaksanaan pembelajaran menggunakan Rope Ladder (Rolade) Physical Activity dalam Study from Home pendidikan jasmani pada anak usia dini sekolah dasar tidak lepas dari pantauan/bantuan orang tua atau pendamping mewakili guru di rumah, oleh karena itu keterlibatan orang tua atau pendamping mewakili guru sangat dibutuhkan pada permainan ini. Berikut merupakan langkah-langkah pelaksanaan pembelajaran permainan Rope Ladder (Rolade) Physical Activity, diantaranya: (a) anak dipersiapkan dengan menggunakan pakaian olahraga lengkap dengan menggunakan sepatu olahraga; (b) membiasakan anak untuk berdo'a terlebih dahulu sebelum memulai Study from Home; (c) mempersiapkan media Rope Ladder (Rolade) Physical Activity yang didalamnya terdapat 100 kotak yang berisi angka bergambar perintah atau aktivitas gerak, pengkocok dadu, dadu, serta miniature anak; (d) memulai permainan dengan mengkocok dadu terlebuh dahulu, lalu setelah miniatur anak tiba pada kotak angka, anak melaksanakan perintah aktivitas gerak yang tertera pada gambar (contohnya; melakukan gerakan melompat 10 langkah kedepan), dll; (e) lakukan sistematika permainan secara runut mengikuti perintah pada media pembelajaran Rope Ladder (Rolade) Physical Activity bergantian antara anak dan orang tua atau pendamping; (f) apabila miniatur anak tiba di kotak yang ada talinya (Rope), maka perintahnya adalah down level atau turun, akan tetapi apabila miniatur anak tiba pada kotak yang bergambar tangga (Ladder) maka next level atau naik. (g) selanjutnya apabila miniatur anak sudah sampai pada kotak 100, maka permainan Rope Ladder (Rolade) Physical Activity dinyatakan telah selesai; (h) biasakan anak mengakhiri pembelajaran atau permainan dengan berdo'a.

Berikut merupakan gude line atau langkah-langkah gerakan Rope Ladder (Rolade) Physical Activity: 


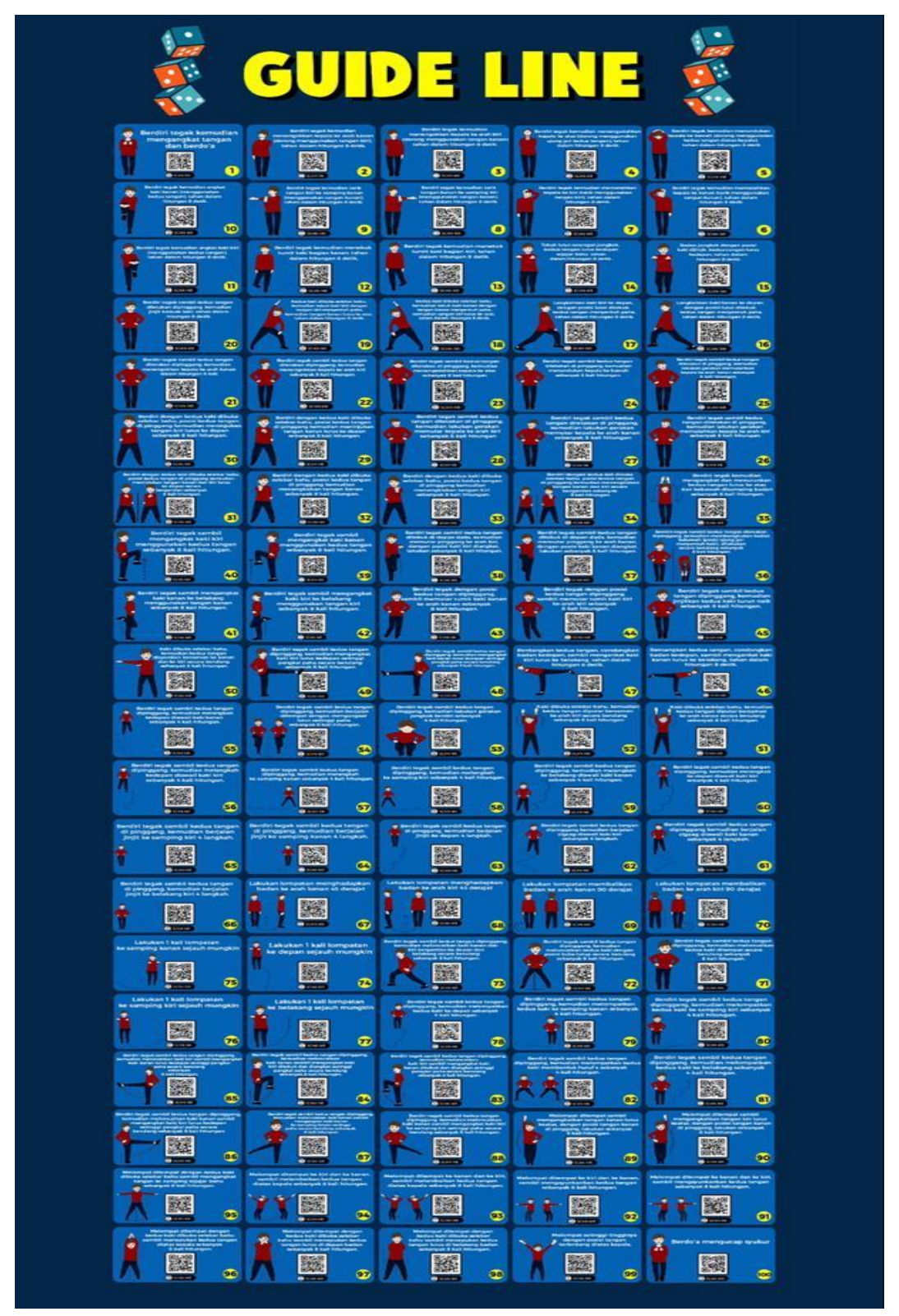

Berdasarkan implementasi pembelajaran tersebut diatas, maka dapat disimpulkan kelebihan dari Rope Ladder (Rolade) Physical Activity dalam pelaksanan Study from Home pendidikan jasmani yaitu dapat mempermudah guru pendidikan jasmani dalam mengiplementasikan Study from Home, menigkatkan minat dan motovasi anak usia dini dalam melaksanakan pembelajaran di rumah (Beghetto \& Kaufman, 2014), dan mengembangkan sikap sabar, ulet, disiplin mengikuti arahan dalam pelaksanaan permainan tersebut (Cho, Chung, Choi, Seo, \& Baek, 2013). Sehingga pada akhiranya variasi permainan aktivitas gerak yang dibuat pada Rope Ladder (Rolade) Physical Activity dapat meningkatkan minat Study from Home Pendidikan Jasmani anak usia dini sekolah dasar. 


\section{METODOLOGI}

Penelitian ini dilakukan untuk mengetahui efektifitas pengembangan inovasi media pembelajaran Rope Ladder (Rolade) Physical Activity dalam meningkatkan motivasi Study from Home anak usia dini sekolah dasar pada pembelajaran pendidikan jasmani. Sehubungan dengan hal tersebut, data yang diperlukan adalah data tingkat minat belajar anak usia dini sekolah dasar kategori Anak Usia Dini pada rentang usia 7-8 tahun yang cenderung diasumsikan akan berubah melalui penerapan inovasi media pembelajaran Rope Ladder (Rolade) Physical Activity dalam penerapannya pada penyelenggaraan Study from Home pada masa darurat penyebaran Covid-19. Penerapan pengembangan inovasi media pembelajaran Rope Ladder (Rolade) Physical Activity diintegrasikan ke dalam pelaksanaan Study from Home pendidikan jasmani yang diberikan selama 8 kali dalam satu bulan dengan intensitas 2 kali dalam satu minggu pada kelompok eksperimen. Maka dari itu metode yang tepat digunakan dalam penelitian efektifitas pengembangan inovasi media pembelajaran Rope Ladder (Rolade) Physical Activity dalam meningkatkan motivasi Study from Home anak usia dini sekolah dasar ini adalah metode eksperimen. Prosedur penelitian melalui metode eksperimen dalam penelitian ini dapat digambarkan melalui bagan alir penelitian berikut ini:

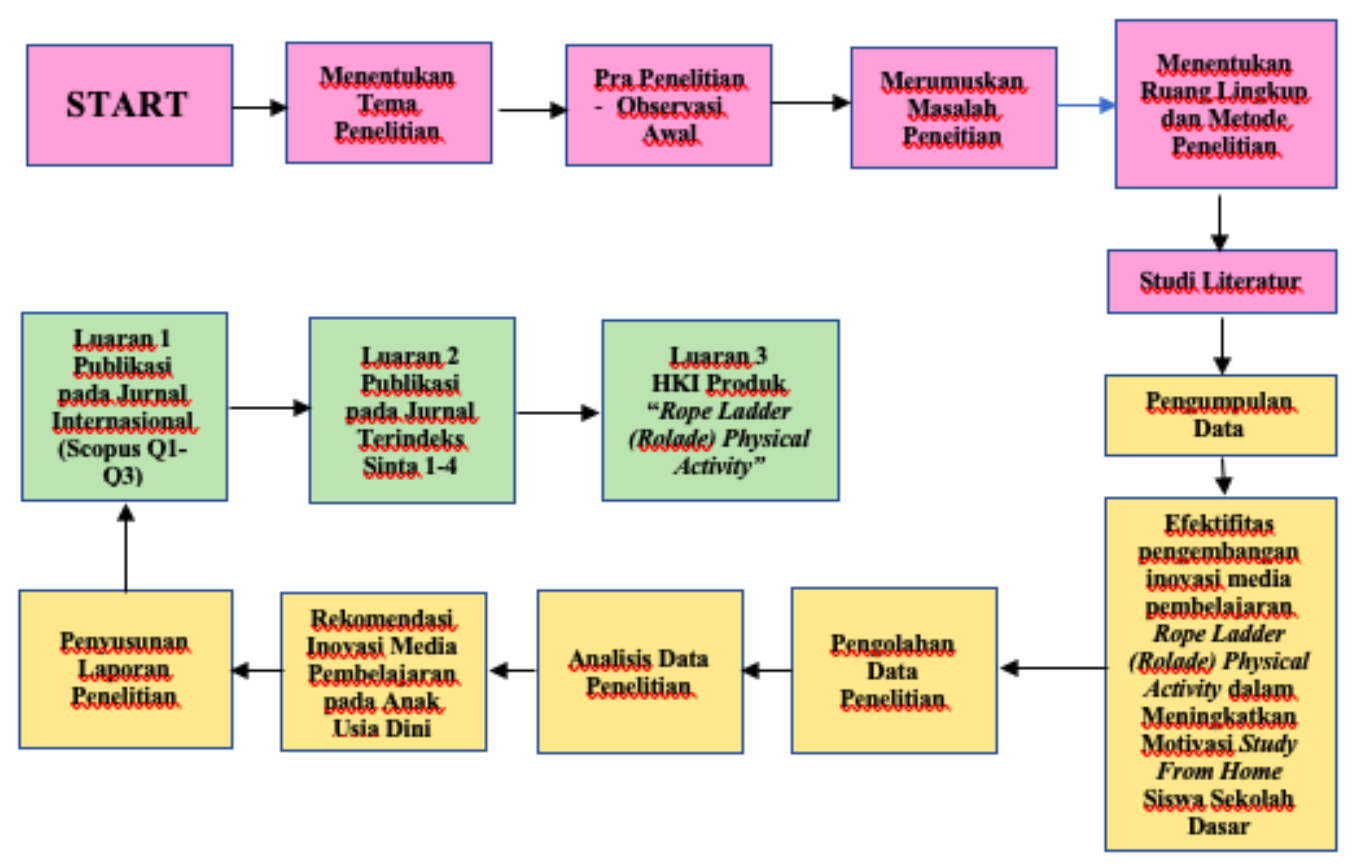

Lokasi penelitian dilakukan di Kabupaten Karawang. Peneliti memilih lokasi ini, sesuai dengan beberapa misi Universitas Singaperbangsa Karawang yaitu menyiapkan sumber daya manusia yang profesional dan berakhlak mulia, serta menciptakan, menerapkan, dan mengembangkan ilmu pengetahuan, 
teknologi, dan seni yang berdaya guna dan berhasil guna. Oleh karena itu untuk mendukung upaya Universitas Singaperbangsa Karawang dalam melaksanakan misinya tersebut, pengembangan inovasi media pembelajaran Rope Ladder (Rolade) Physical Activity dibuat untuk mewujudkan tantangan pengimplementasian Study from Home pendidikan jasmani pada anak usia dini sekolah dasar diaktualisasikan sebagai cara yang tepat untuk tetap mengefektifkan kegiatan belajar mengajar di tengah pandemik Covid-19.

Variabel penelitian yang termaktub dalam penelitian ini yaitu: (a) Variabel bebas (Independent Variable) adalah efektifitas penggunaan inovasi media pembelajaran Rope Ladder (Rolade) Physical Activity dan (2) Variabel terikat (Devendent Variable) adalah minat Study from Home anak usia dini sekolah dasar di Kabupaten Karawang. Desain yang tepat digunakan dalam penelitian ini yaitu The One-Group Pretest-Posttest Design (Fraenkel \& Wallen, 2012). Penentuan subjek penelitian menggunakan penarikan teknik Cluster Random Sampling yang sampelnya terpilih bukan dari orang perorang anak, melainkan kelompok yang selanjutnya disebut cluster. Sehingga terpilih SDIT Lampu Iman Karawang sebagai sekolah kelompok eksperimen pada siswa kelas 1 sejumlah 19 siswa yang merupakan kategori anak Usia Dini pada rentang usia 7-8 tahun. Dalam penelitian ini tidak ada kelas pembanding, akan tetapi menggunakan tes awal (pretest), perlakuan (treatmen), dan tes akhir (posttest) sehingga besarnya efek atau pengaruh efektifitas penggunaan inovasi media pembelajaran Rope Ladder (Rolade) Physical Activity dapat diketahui secara pasti.

Instrumen yang digunakan adalah tes minat belajar anak berupa angket minat belajar yang dikembangkan berpedoman pada Ang Chen, Paul W. and Robert P. Pangrazi (2001) dalam Slameto (2010). Dalam mengumpulkan data dan keterangan yang dibutuhkan, penelitian ini memilih pelaksanan teknik pengumpulan data yang tepat sebagai berikut: (1) Tes Awal (Pretest); (2) Perlakuan (Treatment) sebanyak 8 kali pertemuan; dan (3) Tes Akhir (Posttest). Selanjutnya data yang terkumpul dianalisis dengan menggunakan Teknik analisis Uji-T berpasangan $(p \leq 0.05)$ untuk dapat mengetahui besaran peningkatan gain dari Pretest dan Posttes melalui: (1) Pengujian Rata-Rata dan Simpangan Baku; (2) Pengujian Normalitas; (3) Pengujian Homogenitas; dan (4) Pengujian Hipotesis.

\section{HASIL DAN PEMBAHASAN}

One sample t-test digunakan untuk membandingkan satu sampel dengan parameter tertentu. Prasyaratnya adalah sample tersebut berdistribusi normal. Jadi sebelum melakukan prosedur pengujian dengan menggunakan prosedur one sample t-test, data harus di uji normalitasnya terlebih dahulu dengan ketentuan, jika data berdistribusi normal, maka uji ini dapat digunakan. Jika tidak berdistribusi normal, maka dapat diujikan melalui beberapa langkah, tepatnya yaitu 
menggunakan prosedur statistika non parametrik. Hampir semua teknik pengujian di dalam statistika parametrik mengharuskan data yang akan di analisis adalah berdistribusi normal. Banyak jenis pengujian normalitas seperti uji Liliefors, uji Kolmogorov-Smirnov, Shapiro-Wilk, Anderson Darling, Riyan-Joiner, Cramer-Van Moses, hingga uji Chi-Kuadrat, dan seterusnya. Di dalam paket software SPSS uji normalitas yang dipakai adalah uji Shapiro-Wilk dan uji Kolmogorov-Smirnov yang dikoreksi oleh uji Liliefors.

Untuk memeriksa kenormalan data gain, terlebih dahulu kita lihat grafik normal Q-Q plotnya. Jika kumpulan data yang ada pada gain tersebar dan membentuk pola seperti garis normal dalam grafik tersebut, oleh karena itu disimpulkan data tersebut berdistribusi normal.

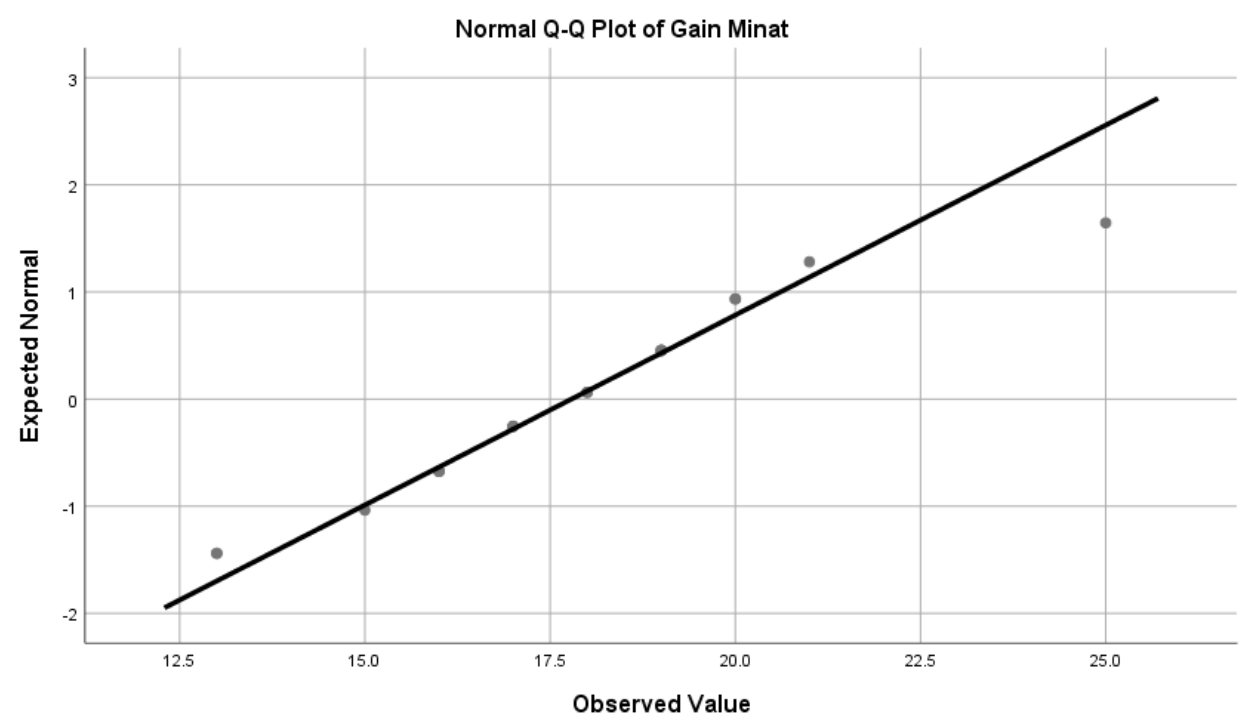

Dalam grafik diatas terlihat data tersebut sangat dekat dengan garis normal dan membentuk pola garis lurus mengikuti garis normal, sehingga disimpulkan bahwa data gain tersebut berdistribusi normal. Untuk lebih meyakinkan bahwa data tersebut berdistribusi normal, maka dapat dilakukan uji formal. Di dalam paket SPSS uji formal untuk normalitas yang digunakan adalah uji Kolmogorof-Smirnov yang dikoreksi oleh Liliefors dan uji Shapiro Wilk. Uji Kolmogorov-Smirnov pada umumnya digunakan untuk ukuran sampel besar ( $\mathrm{n}$ $>25)$, oleh karena itu terhadap uji ini, digunakan koreksi Liliefors agar efektif dalam perhitungan sampel ukuran kecil, sedangkan uji Shapiro-Wilk sangat baik digunakan untuk ukuran sampel kecil $(n \leq 25)$. 


\begin{tabular}{|c|c|c|c|c|c|c|}
\hline \multicolumn{7}{|c|}{ Tests of Normality } \\
\hline & \multicolumn{3}{|c|}{ Kolmogorov-Smirnov ${ }^{a}$} & \multicolumn{3}{|c|}{ Shapiro-Wilk } \\
\hline & Statistic & $\mathrm{df}$ & Sig. & Statistic & df & Sig. \\
\hline Gain Minat & .123 & 19 & $.200^{*}$ & .952 & 19 & .423 \\
\hline
\end{tabular}

Berdasarkan hasil output SPSS seperti di atas, diperoleh nilai statistik untuk uji Shapiro-Wilk sebesar 0,952 dengan nilai p-value (sig.) sebesar 0,423, hal ini diperkuat oleh uji Kolmogorov-Smirnov dengan nilai statistik sebesar 0,123 dengan nilai sig. sebesar 0,2. sehingga pada taraf signikansi 0,05. Diperoleh bahwa nilai sig. kedua uji tersebut $>0,05$ (nilai taraf signifikan), sehingga disimpulkan untuk menerima $\mathrm{H}_{0}$ dan dapat dikatakan bahwa gain minat dalam penelitian tersebut berdistribusi normal. Karena data gain ternyata berdistribusi normal, maka selanjutnya dapat dilakukan pengujian one sample t test. Dengan hasil berikut ini.

One-Sample Statistics

\begin{tabular}{|c|c|c|c|c|}
\hline & $N$ & Mean & Std. Deviation & $\begin{array}{l}\text { Std. Error } \\
\text { Mean }\end{array}$ \\
\hline Gain Minat & 19 & 17.79 & 2.820 & .647 \\
\hline
\end{tabular}

Dari data diatas diperoleh gambaran secara deskriptif yaitu rata-rata gain tersebut adalah 17,79 dengan standard deviasi 2,820, standard error rata-rata sebesar 0,647, dengan ukuran sampel (banyaknya Data) sebanyak 19.

Output spss berikut ini memperlihatkan one sample $t$ test. pada Test value = 0 menyatakan bahwa parameter yang digunakan untuk membandingkan gain tersebut adalah nol. Terdapat beberapa cara untuk menarik kesimpulan berdasarkan tabel ini:

\section{One-Sample Test}

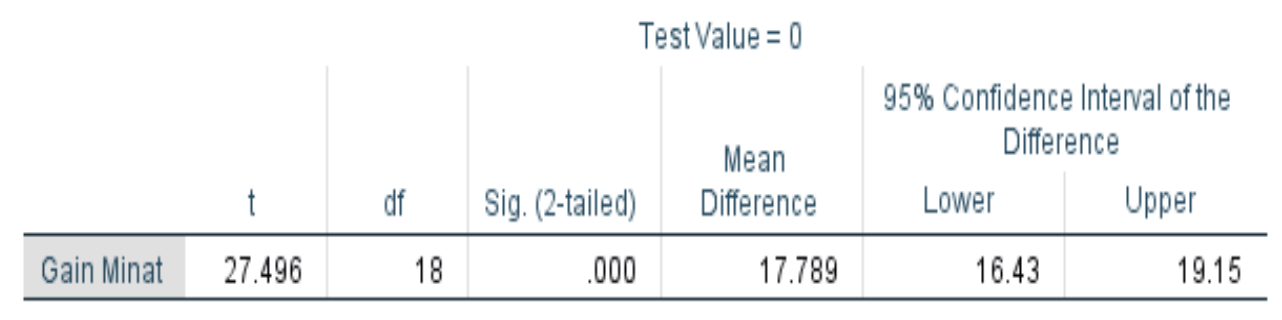

Cara pertama dengan membandingkan nilai $|t|$ dengan nilai tabel (nilai t yang ada dalam tabel statistik), jika $|\mathrm{t}|>$ dari tabel, maka tolak $\mathrm{H}_{0}$. Selain dari itu terima $\mathrm{H}_{0}$. Cara kedua dengan membandingkan nilai sig.(2-tailed) dengan taraf signifikansi, jika nilai sig (2-tailed) $<$ taraf signifikansi, maka tolak $\mathrm{H}_{0}$. Selain dari itu terima $\mathrm{H}_{0}$. Nilai sig.(2-tailed) hanya berlaku pada pegujian 2 pihak, untuk uji satu pihak, nilai sig. $=1 / 2$ nilai sig.(2-tailed). Cara ketiga dengan melihat interval 
confidence, jika di dalam interval konfidensi (batas bawah dan batas atas) memuat nol, maka tolak $\mathrm{H}_{0}$. Selain dari itu terima $\mathrm{H}_{0}$.

Pada umumnya, untuk menarik kesimpulan, kita hanya menggunakan salah satu dari ketiga cara di atas. Lazimnya, untuk perhitungan secara manual, kita menggunakan cara pertama, sedangkan untuk perhitungan menggunakan computer (software statistika), kita menggunakan cara kedua. Sedangkan cara ketiga sangat jarang digunakan kecuali hanya untuk keperluan perhitungan dalam matakuliah statistika saja.

Berdasarkan tabel di atas: Untuk taraf signifikansi $5 \%(=0,05)$, Nilai sig.(2tailed) $=0,000<0,05$. Pada $95 \%$ convidence interval of the difference diperoleh batas bawah sebesar 16,43 dan batas atas sebesar 19,15 ternyata tidak memuat nol. Sehingga disimpulkan untuk menolak $\mathrm{H}_{0}$ dengan kata lain bahwa terdapat perbedaan yang signifikan nilai pra test (pretest) dan pasca tes (posttest) pada penelitan tersebut.

Prosedur 6 langkah dalam pengujian hipotesis untuk output SPSS di atas. Berdasarkan hasil perhitungan dari tabel dari output SPSS di atas dan dengan menggunakan prosedur pengujian hipotesis 6 langkah seperti berikut ini: Untuk uji dua pihak

1) $H_{0}: \mu=0$

2) $\mathrm{H}_{1}: \mu \neq 0$

3) Taraf signifikan $=0,05$

4) Kriteria penolakan $\mathrm{H}_{0}$ : sig. (2-tailed) < taraf signifikan

5) Perhitungan: berdasarkan perhitugan menggunakan SPSS seperti pada tabel diatas diperoleh nilai $\mathrm{t}=27,496$ dengan sig. (2-tailed) $=0,000<0,05$.

6) Simpulan: tolak $\mathrm{H}_{0}$ dan dengan kata lain terdapat perbedaan yang signifikan (nyata) pada nilai pra test (pretest) dan pasca test (posttest).

Untuk uji satu pihak (pihak kanan)

1) $\mathrm{H}_{0}: \mu=0$

2) $\mathrm{H}_{1}: \mu>0$

3) Taraf signifikan $=0,05$

4) Kriteria penolakan $\mathrm{H}_{0}$ : $\operatorname{sig}=\frac{1}{2} x$ sig.(2-tailed) $<$ taraf signifikan

5) Perhitungan: berdasarkan perhitungan menggunakan SPSS seperti pada tabel di atas diperoleh nilai t sebesar 27,496 dengan sig. $=\frac{1}{2} x 0,000=0,000<$ 0,05 .

Simpulan: tolak $\mathrm{H}_{0}$ dan disimpulkan bahwa nilai pasca test (post-test) memang lebih baik daripada nilai pra test (pre-test).

\section{PEMBAHASAN}

Inovasi media pembelajaran dalam pendidikan jasmani pada anak usia dini yang dinamakan Rope Ladder (Rolade) Physical Activity ini merujuk pada permainan ular tangga yang dikenal di masyarakat pada umumnya. Rope Ladder (Rolade) Physical Activity merupakan media pembelajaran berbasis permainan berupa Rope (tali) Ladder (tangga) Physical Activity (aktivitas fisik) yang dibuat menyerupai permainan ular tangga, akan tetapi peraturan permainan di dalamnya dibuat sebuah peraturan baru dengan menyertakan aktivitas fisik, sehingga 
pembelajaran pendidikan jasmani yang berjalan menjadi lebih menarik serta tidak monoton. Oleh karena itu, kebaruan serta keunikan dari permainan Rope Ladder (Rolade) Physical Activity dibandingkan dengan permainan ular tangga pada umunya ialah pada Rope Ladder (Rolade) Physical Activity setiap nomor pada kotak permainan disertakan perintah aktivitas fisik yang gerakannya disesuaikan dengan aspek gerak perkembangan fisik motorik anak usia dini.

Pelaksanaan pembelajaran menggunakan Rope Ladder (Rolade) Physical Activity dalam Study from Home pendidikan jasmani pada anak usia dini sekolah dasar tidak lepas dari pantauan/bantuan orang tua mewakili guru di rumah, oleh karena itu keterlibatan orang tua mewakili guru sangat dibutuhkan pada permainan ini (Konstantinidou et al., 2014). Dalam hal ini, secara umum minat belajar anak merupakan salah satu toalak ukur utama yang menyokong keberhasilan anak dalam proses pembelajaran yang dilakukan di rumah (Study from Home). Tanpa minat belajar yang dimiliki anak, maka proses mencapai sebuah kesuksesan dalam belajar tentu akan agak sulit diraih. Pakar minat belajar Ang Chen dan Paul W. Darst dalam risetnya pada tahun 200, menyatakan.:

"Situational interest is the appealing effect of unique characteristics students recognize in a learning task during interaction with the task. It occurs when a learning task gives the leaner a sense of novelty and challenge, demand high attention and exploration intention, and generates instant enjoyment during the person task interaction".

Maksud pernyataan diatas ialah minat merupakan suatu dampak yang menarik dari karakteristik anak dalam melaksanakan tugas belajar selama kegiatan belajar mengajar berlangsung. Hal ini bisa terjadi apabila tugas belajar yang diberikan oleh guru pendidikan jasmani dapat memberikan kontribusi tantangan dalam pengajaran yang baru, membutuhkan perhatian yang sangat tinggi dan memotivasi dalam mengekplorasi dan menimbulkan kesenangan selama berkomunikasi dengan orang lain sewaktu melaksanakan tugas belajar yang dia laksanakan. Dalam hal ini, minat anak sangat berdampak positif terhadap hasil pembelaaran, karena melalui minat anak dapat melaksanakan kegiatan yang disenangi dan diminatinya, begitu pula sebaliknya tanpa adanya rasa berminat, anak seyogyanya tidak akan dapat melaksanakan kegiatan pembelajaran dengan semangat dan baik.

Berdasarkan implementasi pembelajaran pendidikan jasmani melalui inovasi media pembelajaran Rope Ladder (Rolade) Physical Activity yang ditreatmenkan kepada anak kelas 1 SDIT Lampu Iman Karawang berdasarkan hasil pengolahan data diatas, maka dapat disimpulkan kelebihan dari Rope Ladder (Rolade) Physical Activity dalam pelaksanan Study from Home anak usia dini sekolah dasar pendidikan jasmani yaitu dapat: (a) mempermudah guru pendidikan jasmani dalam mengiplementasikan Study from Home; (b) menigkatkan minat dan motovasi siswa dalam melaksanakan pembelajaran di rumah (Beghetto \& Kaufman, 2014); dan (c) mengembangkan sikap sabar, ulet, disiplin mengikuti arahan dalam pelaksanaan permainan tersebut (Cho, Chung, Choi, Seo, \& Baek, 2013). Sehingga pada akhiranya variasi permainan aktivitas 
gerak yang dibuat pada Rope Ladder (Rolade) Physical Activity dapat meningkatkan minat belajar Study from Home Pendidikan Jasmani anak usia dini Sekolah Dasar.

\section{SIMPULAN}

Berdasarkan hasil penelitian dengan mengimplementasikan efektivitas pembelajaran pendidikan jasmani pada Study from Home melalui pengembangan inovasi media pembelajaran Rope Ladder (Rolande) Physical Activity yang dilakukan selama 8 kali pertemuan pada anak usia dini sekolah dasar kelas 1 SDIT Lampu Iman Karawang, maka dapat disimpulkan bahwa Rope Ladder (Rolade) Physical Activity dalam pelaksanan Study from Home pendidikan jasmani dapat: (a) mempermudah guru pendidikan jasmani dalam mengiplementasikan Study from Home; (b) menigkatkan minat dan motovasi anak usia dini dalam melaksanakan pembelajaran di rumah (Beghetto \& Kaufman, 2014); dan (c) mengembangkan sikap sabar, ulet, disiplin mengikuti arahan dalam pelaksanaan permainan tersebut (Cho, Chung, Choi, Seo, \& Baek, 2013). Sehingga pada akhiranya variasi permainan aktivitas gerak yang dibuat pada Rope Ladder (Rolade) Physical Activity dapat meningkatkan minat Study from Home pendidikan jasmani anak usia dini sekolah dasar.

\section{DAFTAR PUSTAKA}

Amri Hammami, Basma Harrabi, Magni Mohr. (2019). Physical Activity and Coronavirus Disease 2019 (Covid-19): Specific Recommendations for Home-Based Physical Training. Journal Managing Sport and Leisure. https://doi.org/10.1080/23750472.2020.1757494

Ang Chen,et al. (2001). An Examination of Situational Interest and Its Sources. Journal of Britisth Journal of Education Pyschology.

Cho, Y., Chung, K. Y., Choi, K., Seo, C., \& Baek, E. (2013). The emergence of student creativity in classroom settings: A case study of elementary schools in Korea. Journal of Creative Behavior, 47, 152-169. https://doi.org/10.1002/jocb.29

Dimyati \& Mudjiono, (2006). Belajar dan Pembelajaran. Jakarta: Rineka Cipta.

Enright, E., and M. O'Sullivan. 2012. "Physical Education 'in all Sorts of Corners': Student Activists Transgressing Formal Physical Education Curricular Boundaries". Research Quarterly for Exercise and Sport 83 (2): 255-267. https://doi.org/10.1080/02701367.2012.10599856

Fraenkel, Jack. R., and Norman E. Wallen. (2012). How to Design and Evaluate. Research in Education 8th Edition. Boston: McGraw-Hill Higher Education.

Grammatikopoulos, V., Gregoriadis, A., \& Zachopoulou, E. (2012). Acknowledging the role of motor domain in creativity in early childhood education. In O. Saracho (Ed.), Contemporary perspectives on research in creativity in early childhood education (pp. 159-176). Charlotte, NC: Information Age Publishing.

Hellriegel, Don, Jackson, Susan E., Slocum, John W, (2016). Managing: A Competency-Based Approach. Reviewed in the United States. 
Hennessey, B. A. (2010). Intrinsic motivation and creativity in the classroom: Have we come full circle? In R. A. Beghetto \& J. C. Kaufman (Eds.), Nurturing creativity in the classroom (pp. 329-361). New York, NY: Cambridge University Press.

Hyong Guan, at al. 2020. Promoting healthy movement behaviours among children during the COVID-19 pandemic. Lancet Child Adolesc Health. 4(6): 416-418. https://doi.org/10.1016/S2352-4642(20)30131-

Julia M. Carroll. 2018. Literacy interest, home literacy environment and emergent literacy skills in preschoolers. Journal of Research in Reading, 42 (1), 150-161. https://doi.org/10.1111/1467-9817.12255

Kaufman, J. C., \& Beghetto, R. A. (2013). In praise of Clark Kent: Creative metacognition and the importance of teaching kids when (not) to be creative. Roeper Review, 35, 155-165. https://doi.org/10.1080/02783193.2013.799413

Konstantinidou, E., Gregoriadis, A., Grammatikopoulos, V., \& Michalopoulou, M. (2014). Primary physical education perspective on creativity: The nature of creativity and creativity fostering classroom environment. Early Child Development and Care, 184(5), 766-782. https://doi.org/10.1080/ 03004430.2013. 818989

Naim, Ainun, (2020). Pedoman Penyelenggaraan Belajar dari Rumah dalam Masa Darurat Penyebaran Covid-19. Jakarta: Kemdkbud RI.

Pill, S., \& SueSee, B. (2017). Including Critical Thinking and Problem Solving in Physical Education. Journal of Physical Education, Recreation \& Dance, 88(9), 43-49. https://doi.org/10.1080/07303084.2017.1367741

Rahayu, Ega Trisna, (2016). Strategi Pembelajaran Pendidikan Jasmani (Implementasi pada Pembelajaran Pendidikan Jasmani Olahraga dan Kesehatan). Bandung: Alfabeta.

Tinning, R. 2012. "A Socially Critical HPE (aka Physical Education) and the Challenge for Teacher Education." In Critical Voices in Teacher Education: Teaching for Social Justice in Conservative Times, edited by Barry Down and John Smyth, 223-238. Dordrecht: Springer. https://doi.org/10.1177/0271121410392803 